\title{
Reweaving the Urban Fabric of the Historic Riverfront Townscape of Masjid India, Kuala Lumpur
}

\author{
Mohamad Zafarullah b Mohamad Rozaly ${ }^{1 *}$, Sharyzee Mohmad Shukri ${ }^{2 *}$, Nurul Syala Abd. Latip ${ }^{3}$, Alias Abdullah ${ }^{4}$ \\ ${ }^{I}$ Taylor's University \\ ${ }^{2}$ Infrastructure University Kuala Lumpur \\ ${ }^{3}$ Universiti Sains Islam Malaysia \\ ${ }^{4}$ Universiti Islam Antarabangsa Malaysia \\ *Corresponding authorE-mail: sharyzee@iukl.edu.my
}

\begin{abstract}
This study aims to examine the state of decline in the art of relationship between the urban river and all other elements in the historic townscape using principles of the Integrative Theory with the purpose to identify what binds townscape together and gives its sense of place and what causes the rupture. A qualitative-method case study was conducted in the Masjid India Riverfront District involving a visual survey, townscape appraisal, and content analysis on the morphology of the historic riverfront. The results show that the rupture between townscape and river as context is a product of poor walkability in a riverfront devoid of any setting for meaningful human activities, and the key to reweave the historic townscape is to rediscover what gives its meaning and sense of place.
\end{abstract}

Keywords: Context; setting; sense of place; historic urban riverfront townscape; walking scale.

\section{Introduction}

Urban design is defined as the making of places for people [1]. Central to this phenomenology of sense of place is the idea of context: defined as the environment that constrains and informs all areas of urban design action. Context plays a major role in placemaking especially in historic townscape where the early footprints of a town can be seen as responding to its geographical setting [2, 3]. This is especially true for Kuala Lumpur where the urban river is the defining context that binds and weaves the urban fabric into a tapestry of visual forms and experiences.

\subsection{Issues and Problems}

The historical narrative of Kuala Lumpur began when tin as a commodity was sought after in the burgeoning days of the British Industrial Revolution. At the heart of it is the historic Klang River, once the main mode of transport [4]. As it became derelict in the modernising period, its riverfront townscape too became enmeshed in a state of rupture alongside the disconnected and polluted river, canalised to resemble a monsoon drain without any sense of place. Three major causes identified are the advent of land-based transport, pollution due to rapid urbanisation, and poor implementations of flood mitigation procedures which led to the river's decline in function, form and image respectively [5]. This has resulted in a historic townscape in disarray and a city that backs the river, setting the quest for a "World Class City" [6] to be increasingly difficult. Speaking from the textile metaphor of the urban fabric, our rivers and riverfronts, as it were, are in a state of 'unwoven' from their respective historic townscape [7, 8].

In acknowledging that rivers are "natural, untapped assets", the River of Life was launched in 2012 in an effort to resuscitate the rivers through cleaning, beautifying and spurring economic investment [9]. As of August 2017, 81\% of river cleaning and a further $49 \%$ of beautification are effected. Despite its huge budget of RM4.4 billion, ROL has met with much criticism from experts in the fields of hydrology, engineering, and heritage conservation. Under urban design, river beautification is criticised for its 'failure to consult with experts' as conservationists and architects question the effectiveness of the beautification strategy and the speculative land development which may lead to the destruction of the sense of place of Kuala Lumpur historic townscape [10]. This apparent lack of transparency in the market-driven private development may have the conflicting effect of further restricting "public access and enjoyment" to the riverfronts [11].

\subsection{Aim and Objectives}

It is therefore essential to understand the issues concerning rivers and townscapes so as to avoid further misguided strategies in urban design. This study aims to explore the effects of the river's physical decline on the historic townscape by establishing the factors that bind and integrate riverfront and townscape and there onwards identifying the factors that cause the rupture between both elements. The study shall be significant as it may provide alternative references for the design of a riverfront area with the intention to contextually weave both riverfront and townscape.

\subsection{Conceptual Framework: Townscape and the Art of Weaving}

Relph [12] defines townscape as the view of the street and how it is experienced as a setting, complete with a complex of physical elements alongside people, vehicles as well as the spaces in between. In perceiving the street, it was Cullen [7] who saw 
townscape as the effects, or rather the "art of relationship" between different elements in the urban fabric; an art of weaving the physical elements of varying pattern, grain and texture, creating a sense of drama to the perceiver. The interplay of these overwhelmingly textile metaphor is emphasized by Cullen to have an impact on the emotional response as one observes and experiences townscape [2]. This culminated in the art of weaving to form unique visual composition through the quality of juxtaposition of urban elements, much of which is attributable to historic townscapes of medieval cities, as Tibbalds [8] described with many positive emphasis as compared to modern post-war 'comprehensive redevelopments', where such visual composition is virtually absent as it seems to prefer individual buildings and vehicular traffic over places and people.

\subsection{Walkability, the Integrative Theory and Genius Loci}

In emphasising such relationship between places and people, Tibbalds [8] thereon urged us to focus on the intricacies of places related to the scale of people "walking, not driving" as townscape after all is best viewed and experienced on foot. As people mediate between townscape and walking behaviour, many of the urban design qualities overwhelmingly described in the canon of classic urban design [8] [13] [14] [15] [16] [17] [18] are further identified and categorised by Sternberg [19] under the Integrative Theory to encompass five main principles - 'good form', 'legibility', 'vitality', 'comfort' and 'meaning'. Ewing and Handy [20] further identified and developed the said qualities into operational definitions that will measure the phenomenon of sense of place in real-life context.

Human perception plays a major role in understanding the sense of place $[17,21]$ which has led to Norberg-Schulz's exploration of the spirit of place, the genius loci. River as a natural, topographical theme is one of the morphological symbols of expression and objects of identification which form the essence of the systematic pattern of human settlement [21]. To respect the genius loci is to determine the identity of place of such townscape This study seeks to determine what constitutes the genius loci of the case study area, the Masjid India riverfront townscape (fig. l).

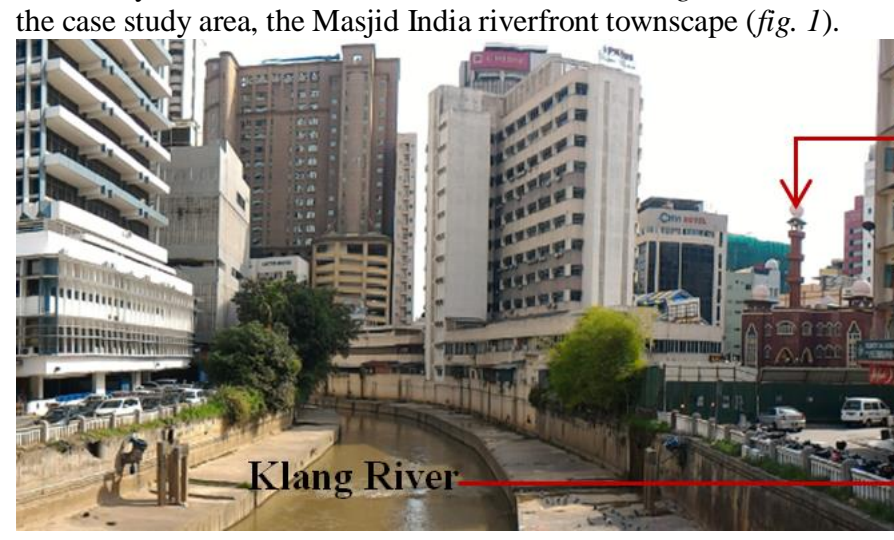

Fig. 1: The Masjid India Waterfront and The Klang River. (Inset: Location Map)

\subsection{Case Study: The Masjid India Riverfront District}

The historic riverfront district is selected within the historical stretch of "...within $50 \mathrm{~m}$ from the edge of both riverbanks or within two lots from the river's edge throughout the city centre area" [22], where the townscape was historically founded and the water is visually noticeable. The case study area is the historic Masjid India riverfront, characterised by a mosque and a traditional shopping enclave within the Kuala Lumpur historic city centre. Its riverfront nature and historical significance in setting the early city footprints meet the research criteria [5]. As evident from fig. 1, the riverfront suffers from poor function, form and image, and a large portion of the townscape backs the river at the time the research was undertaken.

\section{Methodology}

The case study conducted is qualitative in method as the nature of research is to understand and explore a phenomenon within a real life context [23] especially where the boundaries between phenomenon and context need to be established [24]. A field observation was conducted and documented through two main techniques namely a visual survey to analyse the district's perceptual structure; and a townscape appraisal to analyse the visual and experiential fabric of the townscape that gives identity and character; i.e. its physical and behavioural dimensions $[2,3$, 12]. Through a qualitative field observation, the factors causing the rupture between riverfront and townscape are measured and established using attributes modified from the operational definitions of Ewing and Handy [20] that fall under the scope of legibility, urban form, vitality and comfort factors of the Integrative Theory [19] within the walking scale as put forth by Cullen [7], Relph [12] and Tibbalds [8] (refer to fig. 2). Finally, a content analysis is conducted to gather in-depth knowledge on the historical morphology of the historic riverfront context [25].

The categorical relationships between each townscape focus area

(such as streets, enclosures, landmarks, visual units etc.) and riverfront are measured in a simple tripartite observation assigned

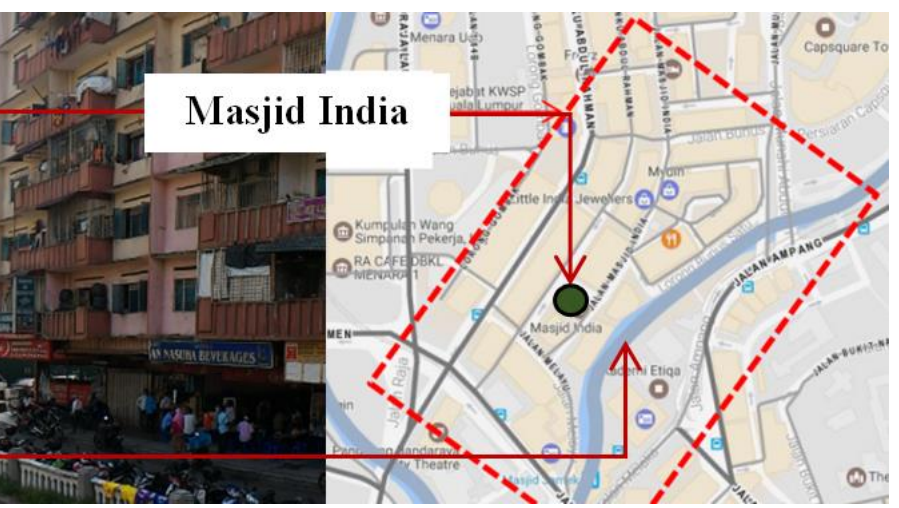

with an ordinal value of 2,1 , and 0 to represent affirmative, partial or negative frequency of occurrences respectively. The ordinal values of these relationships are aggregated based on each subcategory (see fig. 2), and percentages are used to analyse the frequency of occurrences to decide such focus area as either 'good' to represent high level of occurrences (above 75\%); 'fair' to represent moderate level (75\%-37.5\%); or 'poor' to represent low level of occurrences (below 37.5\%) in each respective categories of the Integrative Theory, measured on attributes based on selected operational definitions. 


\section{LEGIBILITY}

\section{Imageability}

Distinctiveness from riverfront

- Recognisability from riverfront

- Reference Points - Placemarkers relevant to riverfront

\begin{tabular}{|c|c|}
\hline Structural Clarity & Linkage Character \\
\hline \multirow{3}{*}{$\begin{array}{l}\text { Navigability to riverfront } \\
\text { - Visual Access } \\
\text { Pedestrian } \\
\text { Permeability } \\
\text { - Orientation of Frontage to } \\
\text { riverfront } \\
\text { - Path and Nodal Clarity to } \\
\text { riverfront }\end{array}$} & $\begin{array}{l}\text { - Frontage Connectivity Along } \\
\text { Linkage to riverfront } \\
\text { - Longitudinal Connectivity } \\
\text { - Lateral Connectivity }\end{array}$ \\
\hline & \multirow{5}{*}{$\begin{array}{l}\text { City Block Character } \\
\text { - Heritage Character } \\
\text { - Connectivity Across Property } \\
\text { Line } \\
\text { - Visual Composition of } \\
\text { Townscape such as } \\
\text { Juxtaposition } \\
\text { - Sense of Unity } \\
\end{array}$} \\
\hline & \\
\hline $\begin{array}{c}\text { VITALITY } \\
\end{array}$ & \\
\hline Complexity & \\
\hline \multirow{4}{*}{$\begin{array}{l}\text { - Diversity in Use in } \\
\text { riverfront } \\
\text { - Human Temporal } \\
\text { Concentration with respect } \\
\text { to riverfront } \\
\text { - Building Typology's } \\
\text { Functionality } \\
\end{array}$} & \\
\hline & $\begin{array}{c}\text { COMFORT } \\
\end{array}$ \\
\hline & \\
\hline & \multirow{3}{*}{$\begin{array}{l}\text { - Scale of Physical Enclosure } \\
\text { - Compensations in Scaling } \\
\text { - Spatial Hardscape } \\
\text { - Spatial Landscape } \\
\text { - Human Walkability Scale } \\
\text { - Street Furniture etc } \\
\text { Climate } \\
\text { - Levels of Obstruction } \\
\text { - Seatings } \\
\text { - Shading } \\
\text { - Lighting } \\
\text { - Universal Design }\end{array}$} \\
\hline Transparency \& Continuity & \\
\hline $\begin{array}{l}\text { - Transparency of Frontage } \\
\text { to riverfront } \\
\text { - Longitudinal Connectivity } \\
\text { of Activities along } \\
\text { riverfront } \\
\text { - Penetrative Lateral } \\
\text { Continuity of Activities }\end{array}$ & \\
\hline Fit: Building And Activities & $\begin{array}{l}\text { Design Coherence } \\
\end{array}$ \\
\hline $\begin{array}{l}\text { - } \text { Activities / Buildings on } \\
\text { Riverfront } \\
\text { - } \quad \text { Robustness } \\
\text { - } \quad \text { Rdaptability } \\
\text { - } \\
\text { Rectrofitability } \\
\text { Reclability }\end{array}$ & $\begin{array}{l}\text { - Physical Consistency } \\
\text { - } \quad \text { Character \& Tidiness } \\
\text { - Street Furniture } \\
\text { - Design Theme } \\
\text { - Street Lighting } \\
\text { - Utilities }\end{array}$ \\
\hline
\end{tabular}

Fig. 2: Integrative Principles, Sub-Categories And The Respective Attributes / Operational Definitions

\section{Findings and Arguments}

The first finding establishes the phenomenology of sense of place and the idea of context based on content analysis of the historical morphology. The second set of findings reveals the effects of physical decline on the riverfront and historic townscape, and the factors that cause the rupture between the two elements are identified. Figures $3 \mathrm{a}$ and $3 \mathrm{~b}$ below illustrate arguments on the followings.

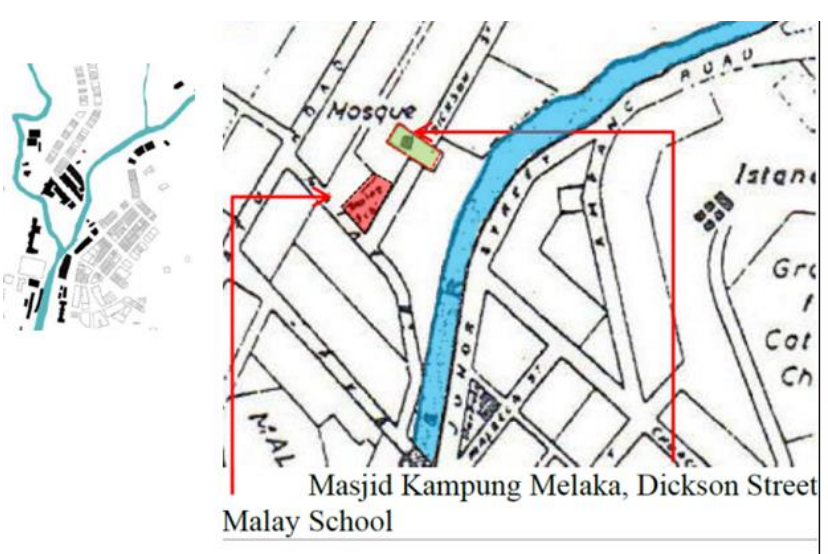

\subsection{Content Analysis}

Content analysis reveals that the mosque has been continuously recorded since 1859. First known as Masjid Kampung Melaka and evolving into what is now Masjid India, it is both a physical and symbolic setting for religious activities (fig.3a); an image so symbolic that has brought about the associative renaming of Dickson Street to Jalan Masjid India in recent times [26]. The orientation at the natural river bend lends the mosque its clear imageability [17] in terms of distinctiveness, legible visual access, a highly recognisable location and excellent relationship with both river and streets which in turn, reinforces pedestrian permeability and interconnectivity in the urban fabric on both streets and river (fig. 3b).

The finding also reveals that being strategically located on the west bank, it lies along the river-main-entrance-qiblat axis which establishes the river as the significant point of entrance thereby reaffirming the role of the mosque as the centre of meaning and together with the Klang River, as the genius loci in the Masjid India Riverfront based on thematic levels such as the river's physical location in urban topography and the mosque's symbolic position in Islamic cosmology and the cultural landscape, establishing both as context in the Masjid India townscape [21]. (Refer fig. 3b).

\subsection{Field Observation: Comfort Factor}

In the second set of findings, it is revealed that at an aggregate of $15 \%$, the comfort factor in the walkable environment scores the lowest among the integrative factors used to identify the relationship between riverfront and townscape. Comfort is defined as a pleasant state of physiological, psychological and physical harmony that exists between a human being and the environment [27]. This means that the low comfort level is key contributor to the rupture and non-integration of the riverfront townscape. Nearly all attributes that define comfort recorded low scores of occurrences, the worst being the absence of street furniture, incoherent street signage and poorly-lit streets at night that contribute to discomfort. At the scale of walking, factors such as connectivity, poor layout and design of paving pattern, planter boxes and the extreme lack of general seatability are observed. Having said this, some streets leading to riverfront however, have fairly comfortable height-to-width ratio $(63 \%)$. The fair occurrence of shading at $50 \%$ is largely due to the five-foot walkways of traditional shophouses and the mature trees provided. However, these do not happen in places towards the riverfront as many are not effectively shaded. The discomfort phenomenon is characteristic of many hot and humid Southeast Asian cities where the dramatically upward trend on air-conditioned environment in public spaces such as the modern indoor shopping mall as the standard indicator of comfort and convenience in the built environment has turned the activities of many Southeast Asian street and townscape indoors [29].

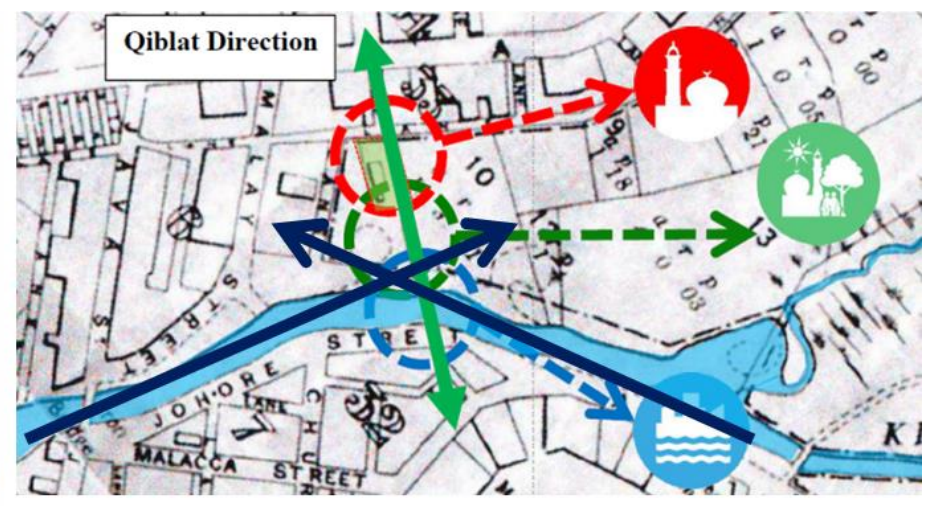

Fig. 3a: 1889 Morphological Record of Mosque and Riverfront [25].

Fig. 3b: Mosque-Main Entrance-River Axis: The mosque lies at the river bend which facilitates imageability. 


\subsection{Vitality Factor}

Vitality is defined as the functional aspects in relation to the activity and uses [1] and was advocated passionately by Jacobs [16] to stress upon the diversity of urban life. The aggregate vitality level of Masjid India stands at a meagre $42 \%$ of occurrences. There is a fair amount of vitality but it barely sets the stage for human activities as a good 58\% has poor street frontage and wall transparency towards and along the riverfront. There are potentially very high scores to be achieved from the diversity of activities and the vibrant traditional shopping activities (63\%) even though the percentage of purposefully-designated waterfront activities is an absolute $0 \%$. The fairly dismal vitality factor contributes to the disintegrated Masjid India riverfront townscape only to be saved by spillover effects of the streets occurring towards the riverfront from qualities defined by complexity in diversity of use, transparency and continuity and fitness of building and activities in the townscape.

\subsection{Other Factors}

Legibility and urban form score poorly (34\% and $21 \%$ respectively) as riverfront is not legible from townscape, vice versa; and the urban form practically backs the river, except in some places.

To summarise the findings, the aggregate score is a poor $28 \%$, which means only less than a third of the elements in townscape is integrated with riverfront. This reaffirms the fact that many postwar developments are not well integrated with the riverfront despite various policies and guidelines introduced [30].

Key focus areas which exhibit good integration with riverfront/townscape are Jalan Ampang, Lorong Bunus 1, Bukit Nenas $(66 \%, 42 \%$ and $40 \%$ respectively) and these are evident from direct relationship they have with riverfront albeit ranging from passable to upper-range poor. They possess better opportunities to integrate with the riverfront. In contrast, the Wisma Yakin, Mosque and Covered Bazaar (15\%, 10\%, 4\% aggregate respectively) are the key focus areas exhibiting the poorest integration with riverfront, evident from the Wisma Yakin which backs the river, the mosque which is physically blocked from riverfront by modern developments, and the Bazaar with negative relationship to riverfront.

The case study confirms the predicament that has plagued many historic cores of cities like Kuala Lumpur: that as a result of rapid urbanisation many are not physically integrated with their contexts [30]. From the findings, the Masjid India Riverfront has less than a third of riverfront integrated with townscape.

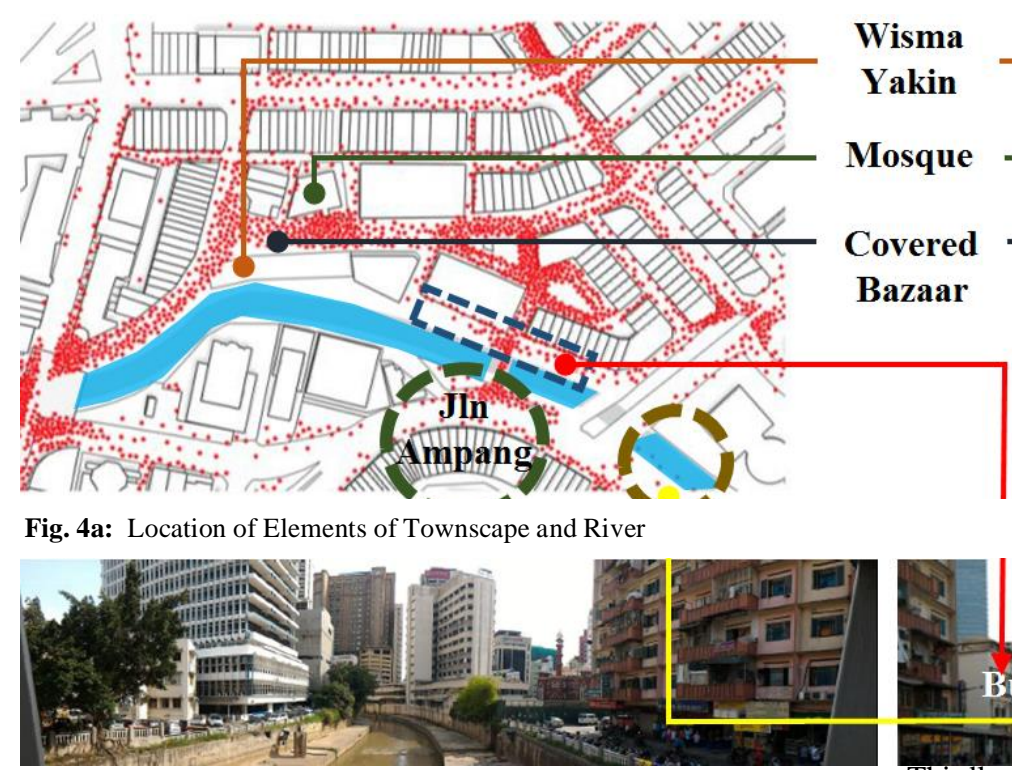

Fig. 4a: Location of Elements of Townscape and River
It is unfortunate that the mosque scored very low due to the modern developments blocking it from the riverfront. As context, it needs to be rewoven into the townscape fabric [7] in order to regain its identity and sense of place [2]. The poor integration between townscape and river as context reflects poorly on the walking dimension of the case study area, especially when its main function is traditional high street shopping. This reaffirms the predicament stated by Tibbalds [11] with regards to modern development's poor relation to the 'scale of people walking' as the findings point clearly to the phenomenon of discomfort as a key contributing factor to the disintegration in the riverfront. The poor integration of riverfront and townscape reaffirms the role of place as setting for human activities as stated by Trancik [28] regarding successful urban form with transparency of frontages as settings for activities. The case study recorded an absence of human activity in its riverfront enclosure to reflect poorly on the identity and character of the place [13, 31,32].

These main findings can be analysed further to form a framework of issues where causes of problem, symptoms and implications can be identified. It can be deduced that the effects of disintegration in townscape is the implication; the result of all the factors which are symptomatic in nature as they manifest as phenomena of the implication in the case study. From literature review, these symptomatic factors may point to a root cause. The discomfort factor experienced in the walking dimension is in fact, a symptom that points to a more central problem.

\section{Conclusion}

It can be concluded that firstly, the rupture between riverfront and townscape is because the river has failed to become a setting for activities to allow for any kind of possible water-related or dependent human activities, simply because there are absolutely no meaningful form of activities in the water body and riverfront, nor are there settings for such activities to help incite greater vitality to repair the rupture between riverfront and townscape. This will lead to discomfort in the walking dimension as poor urban form makes poorly legible places.

Secondly it is concluded that the key to bind and weave riverfront and townscape is to revitalise the context; the genius loci to regain its character and identity in order to restore its sense of place which has been lost during the rapid urbanisation that is sadly mistaken for modernisation. Contextual urban forms and elements in townscape such as the mosque and the riverfront in the case study need to resume as significant settings for human behaviour, so that activities can happen and achieve the vitality so needed.

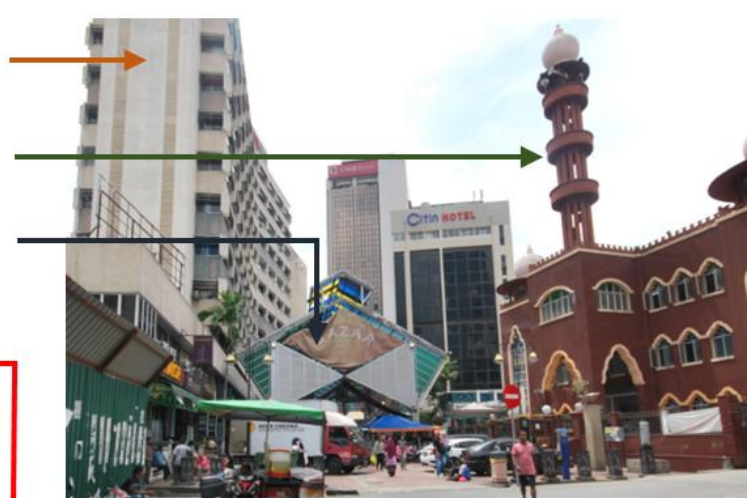

Fig. 4b: Poor Relationship with Riverfront

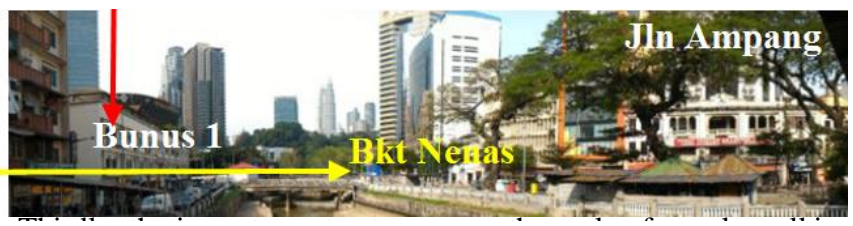

Fig. 4: Focus Areas' Integration with Riverfront in the Masjid India District. 
framework that focuses on the visual and experiential dimensions. To contextually integrate townscape with its genius loci which were lost in plain sight after years of neglect can be brought about by setting objectives to enhance legibility, comfort, vitality and good urban form more at walking speed, and less at driving speed so as to achieve meanings imbued in its character, identity and sense of place. Making the walkable townscape a step more legible, more comfortable, more vibrant is, in effect, making one more bold step, towards the vision of a World Class City.

\section{Acknowledgement}

The authors greatly acknowledge the International Islamic University of Malaysia for a research grant on Transdisciplinary Research Grant Scheme (TRGS)(TRGS16-03-002-00002), Ministry of Higher Education Malaysia for providing invaluable respective data used in this study. Authors sincerely thank all referees for their suggestions to improve the manuscript.

\section{References}

[1] Carmona, M., et al., Public Places - Urban Spaces. 2012: Taylor \& Francis. 320

[2] Shamsuddin, S., Townscape Revisited: Unravelling the Character of the Historic Townscape in Malaysia. 2011: Penerbit UTM Press, Universiti Teknologi Malaysia.

[3] Spreiregen, P.D., Urban Design: The Architecture Of Towns And Cities. 1965: McGraw-Hill.

[4] Gullick, J.M., A History of Kuala Lumpur, 1857-1939. 2000: Malaysian Branch of the Royal Asiatic Society.

[5] Shamsuddin, S., et al., How A City Lost Its Waterfront: Tracing The Effects Of Policies On The Sustainability Of The Kuala Lumpur Waterfront As A Public Place. Journal of Environmental Planning and Management, 2013. 56(3): p. 378-397.

[6] KLCP2020, Draft Kuala Lumpur City Plan 2020. 2006.

[7] Cullen, G., The Concise Townscape. 1961: Architectural Press.

[8] Tibbalds, F., Making People-Friendly Towns: Improving the Public Environment in Towns and Cities. 2012: Taylor \& Francis.

[9] ETP, ETP Economic Transformation Programme. 2010.

[10] Leong, T. Kuala Lumpur's Heritage Buildings Under Threat, Se Asia News \& Top Stories. The Straits Times, 2017.

[11] Ong, K.M. Why Care About 'River Of Life'? Try Rm4.4b For Size. Malaysiakini, 2015.

[12] Relph, E.C., The Modern Urban Landscape: 1880 to the Present. 1987: Johns Hopkins University Press.

[13] Appleyard, D., City Designers and the Pluralistic City. 1969: Institute of Urban and Regional Development.

[14] Bentley, I., et al., Responsive Environments. 2015: Routledge. 152.

[15] Carmona, M. and S. Tiesdell, Urban Design Reader. 2007: Architectural Press. 375.

[16] Jacobs, J., The Death and Life of Great American Cities. 2016: Knopf Doubleday Publishing Group.

[17] Lynch, K., The Image of the City. 1960: Harvard U.P.; Oxford U.P.

[18] Trancik, R., Finding Lost Space: Theories of Urban Design. 1986: John Wiley \& Sons.

[19] Sternberg, E., An Integrative Theory of Urban Design. Journal of the American Planning Association, 2000. 66(3): p. 265.

[20] Ewing, R. and S. Handy, Measuring the Unmeasurable: Urban Design Qualities Related to Walkability. Journal of Urban Design, 2009. 14(1): p. 65-84.

[21] Norberg-Schulz, C., Genius Loci: Towards A Phenomenology Of Architecture. 1980: Academy Editions.

[22] DID, Guidelines on Facing the River Concept, D.o.I.a. Drainage, Editor. 2003, Ministry of Natural Resources and Environment: Kuala Lumpur.

[23] Creswell, J.W., Research Design: Qualitative, Quantitative, and Mixed Methods Approaches. 2014: SAGE Publications.

[24] Yin, R.K., Case Study Research: Design and Methods. 2013: SAGE Publications.

[25] Rosengren, K.E., Advances in Content Analysis. 1981: SAGE Publications.

[26] Isa, M. and M. Kaur, Kuala Lumpur Street Names: A Guide To Their Meanings and Histories. 2015, Kuala Lumpur: Marshal Cavendish Editions.

[27] Slater, K., Human Comfort. 1985: C.C. Thomas.
[28] BWM, Popular Picture History Resources. 2013, Badan Warisan Malaysia: Kuala Lumpur.

[29] Winter, T., An Uncomfortable Truth: Air-Conditioning and Sustainability In Asia. Environment and Planning A, 2013. 45(3): p. 517-531.

[30] Latip, N.S.A., T. Heath, and M.S. Liew, A Morphological Analysis Of The Waterfront In City Centre, Kuala Lumpur. 2009.

[31] Tugnutt, A. and M. Robertson, Making Townscape: A Contextual Approach To Building In An Urban Setting. 1987: Mitchell.

[32] Rapoport, A., History and Precedent in Environmental Design. 2013: Springer US. 